\title{
Moving from Marketization to Marketing of Higher Education: The Co-Creation of Value in Higher Education
}

\author{
Kimberly M. Judson ${ }^{1} \&$ Steven A. Taylor ${ }^{1}$ \\ ${ }^{1}$ College of Business, Illinois State University, Normal, Illinois, USA \\ Correspondence: Kimberly M. Judson, Illinois State University, Normal, Illinois, USA. E-mail: \\ kmjuds2@ilstu.edu
}

Received: September 5, 2013 Accepted: November 20, 2013 Online Published: January 23, 2014

doi:10.5539/hes.v4n1p51 URL: http://dx.doi.org/10.5539/hes.v4n1p51

\begin{abstract}
"The most important issue confronting educators and educational theorists is the choice of ends for the educational process. Without clear and rational educational goals, it becomes impossible to decide which educational programs achieve objectives of general import and which teach incidental facts and attitudes of dubious worth." (Kohlberg \& Mayer, 1972, p. 449)

Keyword: marketization, higher education, student satisfaction, service quality, enhanced human capabilities, value co-creation

\section{Introduction}

Universities in the United States today often proudly proclaim achievements in student satisfaction across their marketing communications. The marketing promise is that a student will be happy and satisfied upon graduation if tuition dollars are paid to a specific university. Such claims are often supported with promises of greater employability upon graduation. While some of this promise appears to be true from a socioeconomic perspective, a growing body of literature suggests that educational delivery in the United States today generally has less influence on intellectual and personal growth (Arum \& Roksa, 2011; Holbrook, 2005; Vargo \& Lusch, 2004; Wilke \& Moore, 2003). Arum and Roksa (2011) present a recent analysis of current university students' academic and social experiences in colleges and conclude that a significant proportion of students demonstrate no significant improvement in a range of skills including critical thinking, complex reasoning, and writing. They attribute this impotence of learning to a growing student body distracted by socializing or employment and institutional cultures that put undergraduate learning close to the bottom of institutional priority lists.
\end{abstract}

We suggest that this apparent attenuation of the priority of learning in academic organizational plans appears be attributable at least in part to recent trends in which institutions are moving toward the marketization of education. In this article, we refer to the marketization of higher education as the increasing influence of market competition on academic life (Williams, 1995). Thus, as academic institutions of higher learning face challenges associated with increasing competition for student tuition dollars, more and more universities are becoming aggressive marketing practitioners. Regretfully, however, the marketization practices employed by most universities today appear to be based on rather archaic marketing theory (Taylor \& Judson, 2011). We will demonstrate that (1) these emerging marketization practices tend to be more sales-oriented than marketing oriented (i.e., marketization is not marketing), and (2) such practices lead to arguably dangerous self-reinforcing pressures which appear to focus primarily on stakeholder satisfaction instead of learning, thereby, helping to explain the observations of Arum and Roksa (2011). We call for the adoption of marketing practices within institutions of higher learning that are more consistent with emerging marketing theory. Specifically, we call on universities to focus on longer-term value co-creation (as opposed to the delivery of perceived value). In support of our call, we propose a framework for measuring marketing "success" in universities that focuses on enhancing human capabilities instead of the growing emphasis on student satisfaction and employment.

\section{The Marketization of Higher Education}

A prevalent trend in higher education today in the United States is focus on marketization practices in higher education (Hemsley-Brown \& Lowrie, 2010; Taylor \& Judson, 2011). The recent general movement toward the marketization of university education can be historically traced to political foundations that resulted in an 
increased emphasis on personalization in pedagogy (Taylor \& Judson, 2011). These pressures have been exacerbated across the United States by trends related to how university education is funded (Note 1), marked increases in student loans, and the growing demand for institutions to help students secure employment post-graduation. As public support of education continues to decrease across the United States, universities increasingly find themselves competing for student enrollments to fund operational expenses. As funding sources have shifted from public support to tuition sources, the marketing-based strategic response from many institutions of higher learning has been to position themselves as providing more satisfying student experiences that will lead to positive employment outcomes upon graduation.

The marketization of university education has variously been referred to as both an "epidemic" (Natale \& Doran, 2012) and as a "paradigm shift" in the arguments underlying the delivery of university education throughout the Western world (Newman \& Jahdi, 2009). Unfortunately, amidst the trend toward marketization, there is evidence that educational outcomes are not improving (Arum \& Roska, 2011). Whitty and Power (2000) conduct an analysis of historical trends across the United States, England, Australia, and New Zealand and conclude that they all display common tendencies toward extensive marketization policies. However, these authors conclude that the purported system-wide benefits of marketization of education have yet to be realized. (Note 2) Moelsworth, Nixon, and Scullion (2009) specifically lament the marketization of university education as eroding the transformation of students into scholars and critical thinkers in favor of considering students as consumers. Natale and Doran (2012) go so far as to characterize the trend as an ethical dilemma. In short, we find little evidence advocating the benefits of marketized higher education and emphases on student satisfaction beyond universities' short-term financial considerations, particularly through the lens of learning.

\subsection{The Decline of Higher Education as a Public Good}

The growth of the marketization of education perspective is further exacerbated by the diminishing view of higher education as a public good (i.e., a shared resource and responsibility) as opposed to the view of higher education as an (individually purchased) private commodity. Lynch (2006) bemoans the results of marketization of education for reasons including: (1) it does not appear to open access to education or educational institutions; (2) the process is essentially asking universities to produce commercially-oriented professionals rather than public-interest professionals; (3) changing cultures to adopt a new role for higher education in society (from academic to operational); (4) the threat to critical voices in society; and (5) the regulation of publications and knowledge. These results appear to align well with the evidence of Cucchiara, Gold, and Simon (2011) who present qualitative evidence of how marketization trends are consequentially affecting education corporate governance structures, increasing an emphasis on communications, leading to widespread contracting out of services, increasing school choice, and increasing the focus on customer service. In the end, we cannot envision a reduction of marketization pressures for the foreseeable future. We ultimately concur with Lynch (2006) and Cucchiara et al. (2011) who both call for universities to ensure some measure of protection of the public-good goals of research and teaching.

Whitty and Power (2000) assert that most commentators view marketization as referring to the development of quasi-markets related to some combination of parental choice and school autonomy, together with lesser or greater degrees of public accountability and government regulation. (Note 3) Molesworth et al. (2009) argue that "market-led" universities respond to consumer calls by focusing on the content students want at a market rate (e.g., students often seek to "have a degree" rather than "be learners"; see Taylor, Goodwin, Melton, \& Hunter, 2011a). We suggest that the response by "market-led" institutions of higher learning toward marketized models is more akin to a sales orientation than a true marketing orientation. Consequently, the next section makes the argument that "marketization" is not the same thing as "marketing."

\section{3. "Marketization" Is Not "Marketing"}

While institutions of higher learning embrace marketization practices in response to changing market conditions, these shifts do not appear to appreciate evolving marketing theory and practices. Vargo and Lusch (2004) articulate how marketing has traditionally had a dominant logic based upon the exchange of "goods," most often in the form of manufactured output. This perspective has focused on tangible resources, embedded value (i.e., delivered value), and transactions. The traditional classroom lecture model would be consistent with this perspective. However, marketing theory and practice today instead rely on a service-based dominant logic which focuses on value co-creation and long-term returns on marketing investments through relationship marketing (Sheth \& Parvatiyar, 2000) and loyalty (Heskett, Sasser, \& Schlesinger, 1997; Rust, Lemon, \& Narayandas, 2005). (Note 4) Thus, Chapelo's (2010) conclusion that universities are struggling with brand management efforts should not appear surprising. Table 1 presents some of the differences between Marketing's traditional 
and current views specific to the delivery of higher education. A review of Table 1 makes clear the different goals and advocated methods between marketization versus marketing approaches to higher education. Unfortunately, consistent with the arguments of Taylor and Judson (2011), an emphasis on marketization has some disturbing implications.

Table 1. "Marketization" versus "marketing"

\begin{tabular}{|c|c|c|}
\hline Dimension & Emphasis in Marketization & Emphasis in Marketing \\
\hline $\begin{array}{l}\text { Primary Unit of } \\
\text { Exchange }\end{array}$ & $\begin{array}{l}\text { People exchange for goods (e.g., buy } \\
\text { credentials from universities). }\end{array}$ & $\begin{array}{l}\text { People exchange to acquire the benefits of } \\
\text { specialized competencies (e.g., buy service } \\
\text { in the form of growth in knowledge and } \\
\text { skills). }\end{array}$ \\
\hline $\begin{array}{l}\text { Role of the } \\
\text { Customer }\end{array}$ & $\begin{array}{l}\text { The customer is the recipient of goods. The } \\
\text { emphasis is on delivering a high quality } \\
\text { education to students. }\end{array}$ & $\begin{array}{l}\text { The customer is the co-producer of service. } \\
\text { The emphasis is on working together with } \\
\text { students to coproduce life-long learning. }\end{array}$ \\
\hline $\begin{array}{l}\text { Role of the } \\
\text { Professor }\end{array}$ & $\begin{array}{l}\text { Develop and deliver value in the form of a } \\
\text { "quality" course to students (e.g., } \\
\text { knowledge through entertaining delivery). } \\
\text { The lecture-style method is an example. }\end{array}$ & $\begin{array}{l}\text { Develop and co-create value in the form of } \\
\text { a "quality" relationship with the students in } \\
\text { learning (e.g., focus on critical thinking skill } \\
\text { development, coediting work together). }\end{array}$ \\
\hline $\begin{array}{l}\text { Determining } \\
\text { "Value" }\end{array}$ & $\begin{array}{l}\text { Value is determined by the producer (in this } \\
\text { case, the student and other organizational } \\
\text { stakeholders). Emphasis on meeting student, } \\
\text { parent, and industry stakeholders' } \\
\text { self-perceived goals. }\end{array}$ & $\begin{array}{l}\text { Value is perceived and determined by the } \\
\text { consumer on the basis of "value in use." } \\
\text { Emphasis also extends to meeting student, } \\
\text { and societal stakeholders' normative } \\
\text { development goals. }\end{array}$ \\
\hline Goal Emphasis & Perceived job relevance. & Personal growth through life-long learning. \\
\hline $\begin{array}{l}\text { Measures of } \\
\text { Marketing } \\
\text { Success }\end{array}$ & Student, parent, and industry satisfaction. & $\begin{array}{l}\text { Personal growth through life-long learning; } \\
\text { increased social capital. }\end{array}$ \\
\hline $\begin{array}{l}\text { Purpose of } \\
\text { Education }\end{array}$ & Job attainment and success. & $\begin{array}{l}\text { Personal growth through life-long learning; } \\
\text { increased social capital. }\end{array}$ \\
\hline $\begin{array}{l}\text { Primary } \\
\text { Stakeholder }\end{array}$ & Student, parent, and industry. & Student, parents, industry, and society. \\
\hline $\begin{array}{l}\text { Temporal } \\
\text { Orientation }\end{array}$ & Short-Term & Long-Term \\
\hline
\end{tabular}

\section{Implications of Marketization in Higher Education}

We suggest the differences between "marketing" and "marketization" matter. The first reason involves the value perceived by students (and often other university stakeholders). Business students most often perceive the value associated with their education based upon their understanding of the relationship between delivered education and applicability to future job attainment and performance (Taylor, Hunter, Melton, \& Goodwin, 2011b). The resulting implication is that unless students perceive value in educational pursuits they will be neither motivated to engage the process (Brophy, 1999; also see Bagozzi, Gurhan-Canli, \& Priester, 2002 for a goal-theory perspective) nor satisfied with the outcome. This perspective also appears consistent with achievement goal theory (Covington, 2000). However, this presents a conundrum. Students value training/credentialing more so than learning (Taylor et al., 2011a). Learning per se has less intrinsic value than the degree as a credential for many students today. Institutions of higher learning consequently face increasing pressure to train students in practical, job-related matters to achieve student satisfaction. Thus, the markers of "success" have moved from intellectual development to employment-related considerations.

Another implication involves the broader societal normative goals, which are often not congruent with students/industries' training goals. Taylor and Judson (2011) point out that it appears difficult to conceive of long-term value creation vis-à-vis greater learning outcomes under marketized conditions. Specifically, their results suggest that grades (an indicant of learning) are neither endogenous (positively related to) or exogenous 
(antecedent to) a typical retail-oriented service quality/customer satisfaction model vis-à-vis Introduction to Marketing courses. They argue that if student service quality perceptions, satisfaction judgments, and engagement practices are indeed unrelated to grades at the classroom level, then a question exists as to how well a focus on student satisfaction (and perceived relevance) actually engender student involvement in the value co-creation process in education delivery. (Note 5) Consistent with this argument, Taylor et al. (2011b) present evidence that the goals underlying undergraduate marketing students' engagement with their educational experience tend to focus on utilitarian, attribute level considerations mainly related to credentialing for purposes of employment. Consequently, value perceptions based on goal achievement related to training and credentialing are more likely to occur under the marketized model of education. As a result, less long-term value is created for the individual with fewer significant advances in intellectual development (as evidenced by stronger critical thinking and information literacy skills; Weiner, 2011).

We argue that the pervasive emphasis on marketization (rather than marketing) is the fulcrum which forges a higher level of student satisfaction and lower level of student intellectual development. Marketization creates an environment which focuses on performance goals (value delivery) rather than learning goals (value co-creation). Elliott and Dweck (1988) tested a framework in education in which goals are proposed as the central determinants of achievement patterns. The results of this study indicate that students' achievement goals (performance or learning goals) are critical determinants of their behavioral, cognitive, and affective goals. Specifically, when the value of the performance goal was highlighted and students believed they had low ability, they responded to feedback about mistakes with "learned helplessness" and negative affect. When the value of the performance goal was highlighted and students believed they had high ability, they responded to feedback about mistakes with a "mastery-oriented manner" intent on overcoming the obstacles. Interestingly, when the value of the learning goal was highlighted, students' beliefs about their abilities, whether high or low, were irrelevant and students sought to increase competence and opted for more challenging tasks.

What are the psychological underpinnings of these observations? When evaluating an educational experience, students begin their appraisal by considering two aspects of the experience: the motivational relevance and the motivational congruence (Smith \& Kirby, 2009). With motivational relevance, the student asks, "How relevant is this course/program to my needs?" With motivational congruence, the student asks, "How congruent is this course/program to my goals?" Whether or not the experience is relevant and/or congruent elicits different and more intense emotional responses. Marketing literature supports that appraisal emotion (the role of emotion in customer judgments) is related to both satisfaction and perceived value (Hume \& Mort, 2010; Arora \& Singer, 2006; White \& Yu, 2005; Bagozzi, 1997). Sheth, Newman, and Gross (1991) proposed a theory of consumption value based on the perceived utility of functional value (physical attributes), social value (association with socio-economic and cultural groups), emotional value (creation of affective states), epistemic value (desire for novelty and knowledge), and conditional value (contingencies in the situation). Students will determine perceived value of a course by comparing the output (what they get) to the input (what they give) (Yang \& Peterson, 2004). The output is likely to be interpreted according to motivational congruence. Thus, if a student's goal is to pass the class but the goal of the faculty is to increase the student's competence, perceived value will be viewed as incongruent and evaluated as low. Boksberger and Melsen (2011) study the dominant evolvement of transaction-specific values from an individual customer's point-of-view. In the case of higher education, the nature of transaction-specific value (short-term) will focus on service quality, customer satisfaction, consumption values, perceived value, benefits, and sacrifices. In contrast, the nature of end-state (long-term) value will focus on quality of life and wellbeing. It is this difference that forms the basis of our proposed model.

Consequently, there are some very pragmatic implications of a marketization perspective in education. When institutions choose to evaluate themselves according to transaction-specific value rather than end-state value, they are aligning with value delivery (giving students with "learned helplessness" what they want to overcome obstacles) rather than value co-creation (providing challenging tasks for "mastery-oriented" students so they can increase competence). Regardless of the student's position on the "learned helplessness/mastery-oriented" spectrum, an institution will be evaluated according to their ability to facilitate intellectual development (long-term) if the students' goals are congruent with the institution's goal to enhance competence. Concrete goals include credentialing and obtaining a degree, while abstract goals include intellectual development and developing critical thinking skills. We suggest that it is the primary function of higher education to move students toward abstract intellectual goals such as higher levels of intellectual development (e.g., critical thinking, synthesis, evaluation). (Note 6)

In short, we assert that the marketization of education with its consequent emphasis on training (often more closely associated with lower levels of intellectual development such as recognition of terms and concepts) could 
ultimately lead to poor long-term outcomes for both individuals and society at large. We believe that many educators will agree that educators have some normative responsibilities to not ignore the movement away from educational rigor associated with the marketization of education (Arum \& Roksa, 2011).

\subsection{Measuring "Success" Under Marketized Education}

The issues identified above appear to have created at least two more significant problems for marketing educators. The first is a frequent practice of an almost exclusive emphasis on student evaluations (i.e., satisfaction) in assessing faculty performance related to the delivery of pedagogy (Chen \& Hoshower, 2003; Clayson \& Haley, 2011; Culver, 2010; Denson, Loveday, \& Dalton, 2010; Dolnicar \& Grun, 2009; Ewing, 2012; Germain \& Scandura, 2005; Langbein, 2008; Pounder, 2007; Shevlin, Bantard, Davies, \& Griffiths, 2000). However, the problems inherent in using student evaluations to assess faculty performance in the delivery of pedagogy are well known. Clayson and Haley (2011) present evidence that the validity of student evaluations is often violated because students falsify responses. More troubling was their observation that many students do not consider such information falsification unethical. Clayson and Sheffet (2006) similarly present evidence that student perceptions of the instructor's personality are strongly related to evaluation of faculty by students. Dolnicar and Grun (2009) identify potential response style contamination of student evaluation data related to cross-cultural responses. Lala and Priluck (2011) present evidence that predictors of intentions to complain differ based upon the target of complaint behavior (school, friends, or unknown others) and the mode of complaint (in person or using the web). Together, these studies generally call into question the validity of student evaluations as a means of faculty evaluation of pedagogy (Shevlin et al., 2000; Madichie, 2011). Such criticisms of validity are potentially damning.

The second problem for marketing educators is grade inflation, which is also related to marketization trends (Pounder, 2007). Ewing (2012) presents empirical evidence supporting the conclusion that regardless of the estimation procedures employed, there exists a significant positive effect of relative expected grades on student evaluation scores. (Note 7) He further argues that there is a growing incentive for instructors to grade leniently. Langbein (2008) similarly present empirical evidence supporting the conclusions that actual grades have a positive effect on student evaluations of teaching. Zadeh, Gharakhani, and Afrougheh (2011) present evidence of a significant relationship between gender, indigenousness, and academic background of the instructor with the students' expectation of grades. Culver (2010) presents evidence that students' engagement with course materials significantly moderates the relationship between expected grades and overall rating of instructors. Germain and Scandura (2005) link grade inflation to consumerism by universities that now compete for students. They argue that students' individual differences and grade inflation serve as sources of bias in teaching evaluations. Oleinik (2009) makes the explicit link between the marketization of education and grade inflation by specifically arguing that the marketization of education has led to grade inflation by substituting criteria specific to the search for truth by criteria of quality control generated from outside of academia moving universities closer to commercial enterprises. Lippman, Bulanda, and Wagenaar (2009) similarly relate the prevalence of a consumer mentality within students with student entitlement and subsequent grade inflation. (Note 8) Love and Kotchen (2010) present evidence that placing more emphasis on course evaluations exacerbates the problem of grade inflation, and can even decrease an instructor's teaching effort. Goodwin (2011) characterizes grade inflation as "killing with kindness." Figure 1 summarizes the sequence of events that have largely led to today's challenges for marketing educators. 


\section{The Trend Toward Marketization of Education}

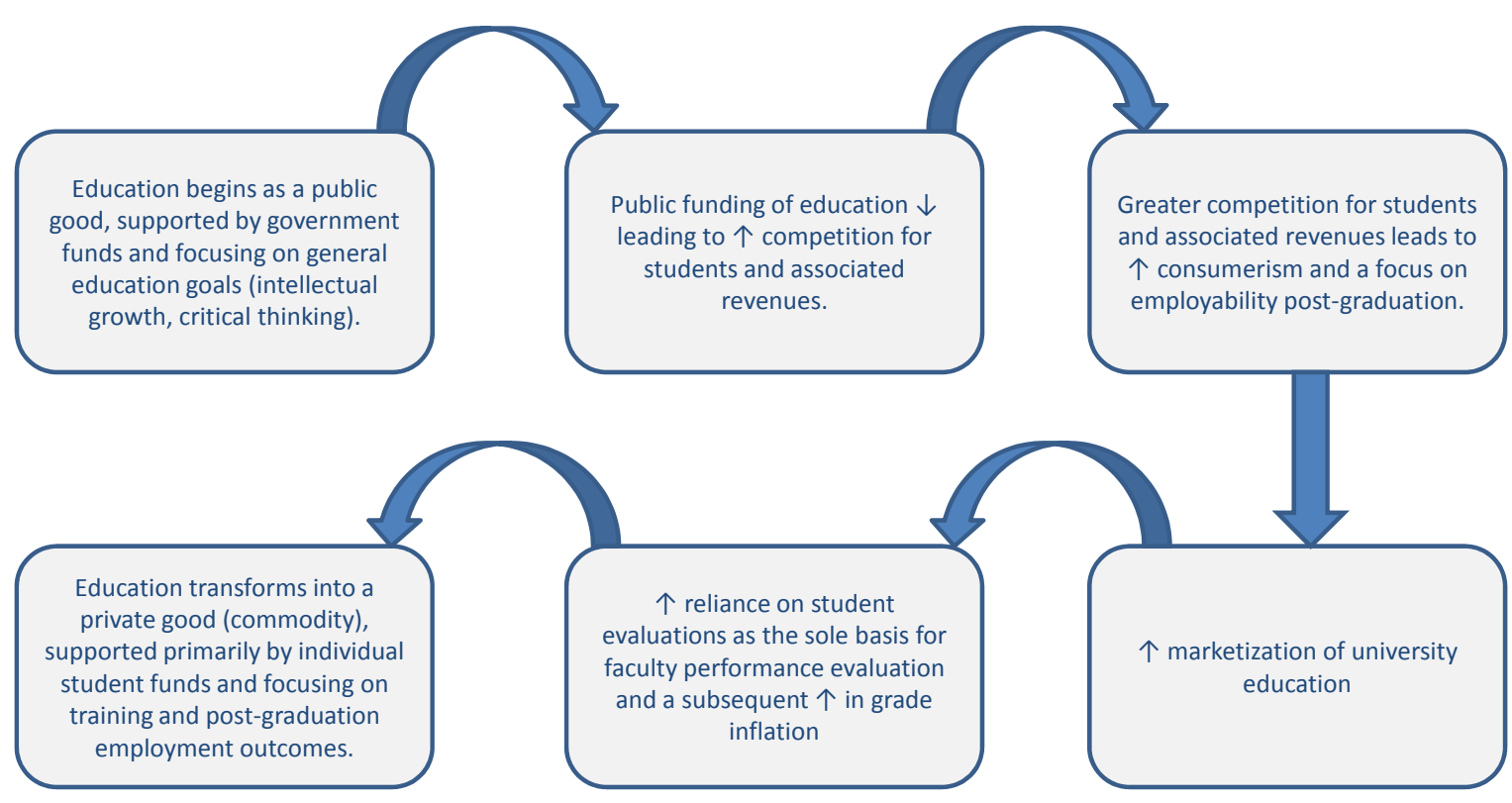

Figure 1. The trend toward marketization of education

\subsection{Recognizing the Evolution of Forces That Reinforce Marketization Practices}

We suggest that there exists growing institutionalization of practices that reinforce an emphasis on marketization instead of marketing. For example, there is little argument that faculty are a major component of the educational delivery process, and their interaction with students contributes to course evaluations. Denson et al. (2010) point out that the main goals of student course evaluations are to obtain defined/practical feedback regarding course and teaching for purposes of improving pedagogy. To this point we have argued that universities are currently experiencing growing pressure to move away from general life-long learning models of education toward models more akin to workforce training. The standard of "good" teaching begins to increasingly rely on student satisfaction scores, not learning outcomes. Consequently, students are relieved of responsibility for learning as faculty members are forced to carry increasingly larger shares of pedagogical relationship responsibilities through an emphasis on teaching (an emphasis on faculty inputs instead of student outcomes). As seen above, the reasons underlying these pressures are well understood and the associated risks are unpalatable.

So what can be done to protect learning and intellectual development under conditions that instead reward marketized university education? We suggest that a useful starting place is to dialogue as disciplines and faculty in hopes of reaching commensurable teaching standards that emphasize intellectual development and learning in addition to student satisfaction and engagement. Importantly, we are not advocating no longer using student evaluations as criterion for assessing faculty performance in "teaching." However, we are arguing against such scores being the sole, or even primary, basis for such evaluative processes. We agree with Madichie (2011) and Pounder (2007) that the time has come to consider alternative methods of assessing the value associated with co-created pedagogy. First, we will argue in the next section that what is being assessed in terms of faculty performance must be reconsidered to more closely align with life-long learning, often an explicitly stated university organizational objectives. Second, even if one accepts the veracity of student satisfaction as an appropriate measure of a quality educational experience, operationalizing satisfaction appears difficult at best as 
student satisfaction scores appear relatively serendipitous, culturally bound, and vary across groups (Gruber, Fub, Voss, \& Glaser-Zicuda, 2010; Munteanu, Ceobanu, Bobalsca, \& Anton, 2010). The next section presents some thoughts about how marketing educators might rethink student evaluation processes to better address the issue of validity and to combat the potential negative outcomes associated with the marketization of education. The purpose is to begin a dialogue as to these important considerations.

\section{Adopt a Marketing, Not Marketization, Perspective}

We believe the quotation at the beginning of this article identifies the crux of the key issue facing academicians today, and thus, we support establishing clear educational goals and committing to a marketing perspective in higher education. Kohlberg and Mayer (1972) called decades ago to focus on development (intellectual and moral) in the delivery of education, referred to herein as progressivism. These authors argue for a developmental-philosophic strategy for defining educational objectives which is based upon the works of Dewey and Piaget. Thus, we begin by suggesting that "what" is measured in faculty evaluations should be carefully considered. In short, Kohlberg and Mayer (1972) describe the educational goal of progressivism as the eventual attainment of a higher level or stage of development in adulthood.

Kohlberg and Mayer (1972) assert that the progressive view, with its emphasis on transformation of cognitive structures, has the strongest underlying psychological argument of the available educational ideologies. This requires an educational environment that actively stimulates development through the presentation of resolvable but genuine problems or conflicts. These problems or conflicts should foster thinking in ways which organize both cognition and emotion. Thus, this view perceives "knowledge" as an active change in patterns of thinking which find meaning in a broad set of moral values. Thus, in this view, mature thought emerges as a process of development that is neither direct biological maturation nor direct learning, rather, a reorganization of psychological structures resulting from a person's interaction with their environment. Cognitive structures are transformed over experiences to accommodate a person's external world. Thus, the psychology underlying the progressive view is the long-term value of educational experiences as they relate to development and not the short-term value of the student's immediate experience.

In addition, Kohlberg and Mayer (1972) state that the progressive view has the strongest underlying epistemological argument of the available educational ideologies. Specifically, the progressive view holds that education should meet humanitarian criteria, but, importantly, that a concern for the enjoyment and liberty of the student (i.e., the perspective of marketization) is not in itself equivalent to a concern for their development. Epistemologically, the progressive view derives from attempts to integrate dichotomies of the inner versus outer, the immediate versus the remote in time, and the unique versus the general. This view focuses on the student's experiences in terms of universal and empirically observable sequences of development as a member of a community striving toward societal goals.

We concur with Kohlberg and Mayer (1972) and conclude that current marketization of education trends represent movement away from progressive educational goals to earlier, largely discredited educational objectives based upon both psychological and epistemological arguments. Consequently, we call for efforts to revisit what is measured in faculty evaluations, and more specifically, to move beyond simple student satisfaction scores of faculty performance based on often relatively arbitrary attribute lists.

What does a marketing perspective look like? This approach would focus on life-long learning and personal growth for the student, not on credentialing. Again, we are not suggesting that capturing some form of student perceptions is undesirable. However, we must ensure that what we are capturing is cognitively available to students to relate (e.g., "Faculty are knowledgeable?"), and that measures of faculty performance are also consistent with broader educational goals of other stakeholders such as society at large. We will suggest a framework to stimulate greater discussion in this important area of inquiry and practice. However, first, the issue of appropriate student and societal goals requires discussion.

\subsection{Emphasize Appropriate Student and Societal Goals}

We assert that a movement away from marketization and toward marketing models is in the best interests of students and society alike. While all universities typically brag about their focus on critical (higher order) thinking - often in pursuit of life-long learning objectives - we have previously established the position that current university education systems in the US often neither (1) produces the highest possible level of intellectual growth, or (2) reflects efforts to ensure so through faculty evaluations. Continued pressures toward training models will arguably not change this outcome because they reinforce existing students' goals more related to short-term employment outcomes than long-term individual growth (Taylor et al., 2011b). The risk is for marketing education to become hostage to the serendipitous issues that hold the attention of marketing 
practitioners at a given moment in time. In other words, we strongly endorse an emphasis on greater critical thinking skills and higher levels of educational development in university educational delivery at the individual level of analysis. Such gains promise to make individuals better equipped to make reasoned decisions about what to believe or do. Damer (2013) offers the following reasons why gains in critical thinking benefit individuals and society, including:

- Good arguments help people make better decisions in terms of success in goal achievement.

- Good arguments are particularly important in helping individuals make difficult moral decisions.

- Good arguments promote our general interest in holding only those views that we have reason to believe are true and defensible.

- Good arguments raise the level of thinking and discussion in social, business, and personal contexts.

- Focusing on the quality of arguments is an effective way to resolve personal disputes and settle conflicts.

Thus, we assert that measurable higher-order critical thinking learning objectives in university education are well worth protecting both in terms of assessment of delivered education and in faculty evaluations. An emphasis on marketized education arguably threatens such protections. Importantly, formally assessing the efficacy of growing critical thinking skills in faculty interactions with students is not reasonably within either students' abilities, or arguably individual faculty members themselves. Rather, this is an area of assessment that should be considered using formal mechanisms independent of both the faculty and students involved in any specific class (e.g., external assessment by subject matter experts).

\subsection{A Proposed Theoretical Framework for Faculty Evaluations of Marketing Pedagogy}

Existing faculty evaluation surveys typically ask for student perceptions of attributes related to faculty members themselves, faculty-student interactions, course content, and course management. The basic argument appears based on the service quality $\rightarrow$ consumer satisfaction relationship often observed in marketing (Oliver, 2010). However, since goals are related to satisfaction (Garbarino \& Johnson, 2001; Shiv \& Huber, 2000), this conceptualization only applies if the marketers and consumer have the same goals in terms of exchange. Taylor et al. (2011a) make clear that such is often not the case. We suggest that this is a fatal flaw of models based solely on students' idiosyncratic perceptions or judgments upon which they are often not even capable of making in a reasoned manner (e.g., "My instructor cared about me?").

Rather, we encourage marketing educators to consider embracing more multi-dimensional conceptualizations of faculty performance related to the delivery of pedagogy with a greater focus on student outcomes, not just evaluations. Some of the dimensions proposed below can be measured by self-report student surveys, but some cannot. In short, we are encouraging academicians to augment student perceptual data with an emphasis on university-driven student outcomes. Specifically, consistent with the arguments of Kohlberg and Mayer (1972) we offer for discussion an overall goal of enhancing human capabilities. Proposed general/broad goals of the proposed model to underlie evaluations of faculty performance include increasing the dimensions identified by Pascarella and Terenzini (2005), including intellectual development, psychosocial changes, changes in attitudes and values, and moral development (see Figure 2). 


\section{Enhancing Human Capabilities}

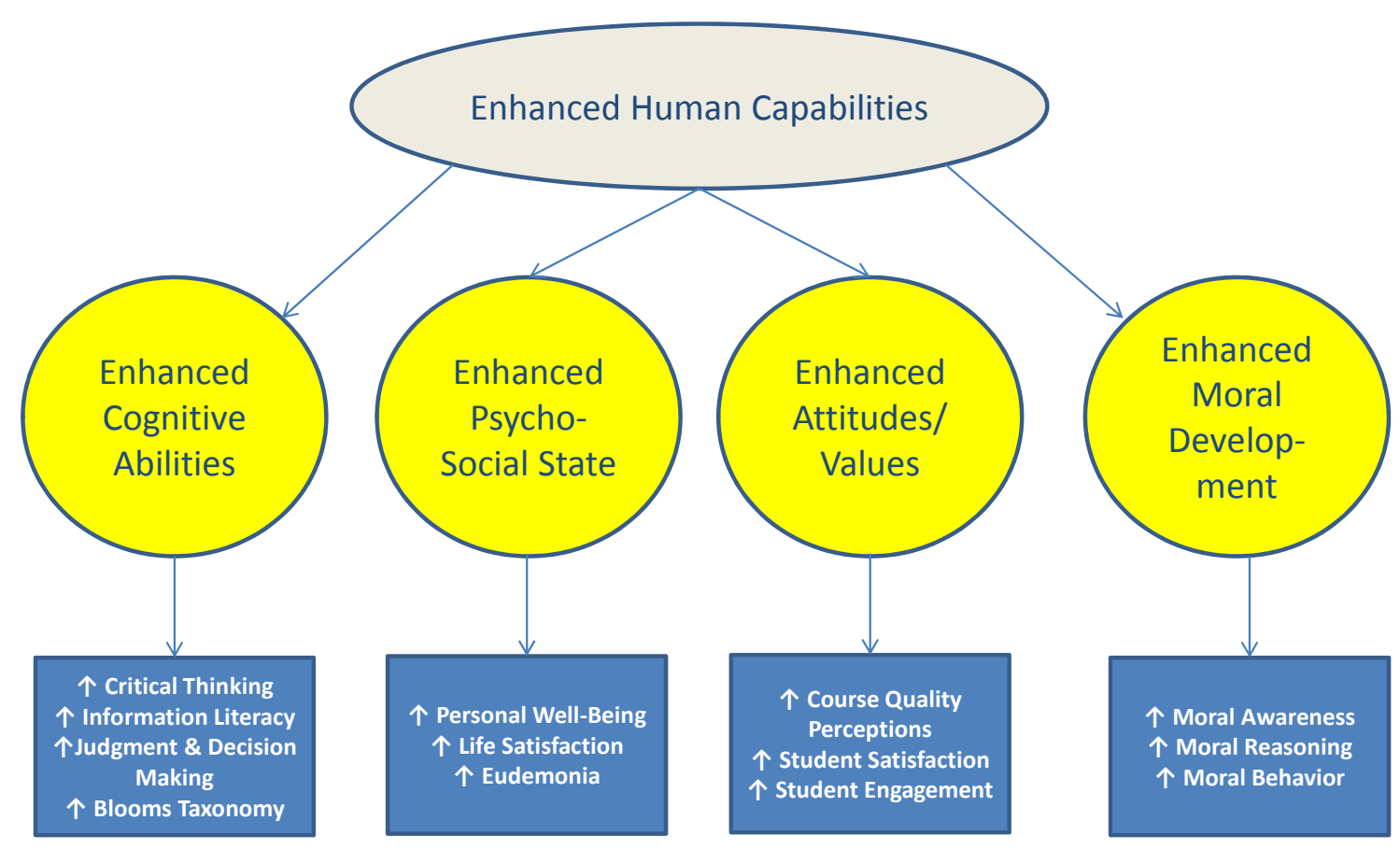

Figure 2. Enhancing human capacities

As a starting point, the model presented as Figure 2 proposes to shift the overall emphasis in faculty evaluation from the traditionally arbitrary student evaluations of faculty "performance" to a more general emphasis of efficacy in enhancing the human capabilities of marketing students. Savulescu, Sandberg, and Kahane (2011) consider competing definitions of the term "enhancement" in this context and conclude that the term, in its broadest sense, means increase or improvement. They identify two key senses of the use of the term: (1) functional enhancement, or the enhancement of some capability or power (e.g., vision, intelligence, health) or (2) human enhancement, or the enhancement of a human being's life. Ultimately, Savulescu et al. (2011, p. 7) conclude that the latter is the notion most relevant to ethical debate and call for a welfarist approach to enhancement, defined as "Any change in the biology or psychology of a person which increases the chances of leading a good life in the relevant set of circumstances." This is the position we adopt herein.

\subsection{Enhanced Cognitive Abilities}

The first area of emphasis we propose should prove non-controversial as it relates to the traditional emphasis of universities to encourage intellectual development, and involves cognitive enhancement. "Enhanced Cognitive Abilities" include life-long learning achievements in support of greater value co-creation in education. In Savulescu et al. (2011), Sandberg defines cognitive enhancement as the amplification or extension of core capabilities of the mind through improvement or augmentation of internal or external information processing systems. Clarke (2011) relates this area to improvements in judgment anddecision making. This area generally seeks to advance individuals along the Blooms Taxonomy of Learning (1956) and would include measures of cognitive development such as critical thinking and information literacy (Weiner, 2011).

Critical thinking as featured in the taxonomies is a complex process that requires higher levels of cognitive skills in the processing of information. According to Choy and Cheah (2009), faculty believe they are developing critical thinking skills in students, when in fact, they are simply putting the material in a simpler form which aids 
in greater comprehension of the subject matter. Overall, Choy and Cheah (2009) found that teachers in higher education perceive that they are teaching critical thinking skills to their students, when they actually do not understand the requirements needed to cultivate critical thinking among students. The movement to a critical thinking curricula is needed according to Flores, Matkin, Burbach, Quinn, and Harding (2012) because most pedagogy is content-based built on deep knowledge. Students with limited cognitive processing skills are unprepared to think critically and thereby become less effective leaders (Flores et al., 2012). Behar-Horenstein and Niu (2011) analyzed 42 empirical studies of teaching critical thinking skills and suggest that institutions should monitor implementation because the same instruction interventions frequently lead to different results. In addition, these authors argue that qualitative data should be used to inform researchers about intervention effects that are difficult to capture with quantitative data. Because most current studies on critical thinking have serious research design limitations, future research is needed to establish causal relationship between intervention and changes in students' critical thinking skills (Behar-Horenstein \& Niu, 2011).

\subsection{Enhanced Psycho-Social State}

The second area of emphasis involves psychosocial enhancement. "Enhanced Psycho-Social State" includes measures of life-long positive influences such as life satisfaction and eudomonia. Pascarella and Terenzini (2005) describe this area as including both students' "self-systems" (e.g., identity, self-concepts, locus of control, well-being) and "relational systems" (e.g., nature of relationships and interactions). We believe it is important for those on the inside of higher education to make eudaimonic psychological well-being and the engagement of college students a top priority because students themselves might not always do so. In other words, long-term life satisfaction, not short-term consumer satisfaction, should be the priority of every institution seeking to protect the well-being of their students.

Ryff and Singer (2008) acknowledge that while eudaimonia is difficult to pronounce and spell, it is also difficult to understand. They describe eudemonia as the idea of striving toward excellence based on one's unique potential. Deci and Ryan (2008) describethe eudaimonic tradition as living life in a full and deeply satisfying manner. Eudaimonic growth is defined as increases in psychosocial maturity and subjective well-being over time (Bauer \& McAdams, 2010). Higgins (2003) suggests that Alasdair MacIntyre's 1981 moral theory calls for a return to Aristotle in the belief that eudemonia is central to professional ethics. He explains that a good is something we simultaneously value for its own sake and for what we believe it contributes to our overall well-being. In the sense that higher education contributes to the well-being of our students, it can enhance society at large and should represent a public good.

\subsection{Enhanced Attitudes/Values}

Importantly, student satisfaction can still be assessed under the dimension entitled "Enhanced Attitudes/Values." Bowden (2011) conducted a study of 474 college students to examine the university's relationship marketing approach. It is important to note that student loyalty was most strongly determined by psychological attachment and a sense of belonging to the brand. Bowden (2011) found that while student satisfaction was a contributing factor, satisfaction alone was insufficient in generating loyalty. This author calls for a more in-depth and proactive strategy to develop and maintain the student-university relationship.

While researchers have suggested new criteria for assessing quality in higher education, most focus on the input of the faculty and/or the institution rather than the output of students as specified in most institutional mission statements. For example, Zineldin, Akdag, and Vasicheva (2011) advocate examining these factors affecting students' perception of cumulative satisfaction: technical, functional, infrastructure, interaction and atmosphere of higher education institutions. Likewise, Gibson (2010) reviewed the major attributes of an educational program that are most commonly found to be significant predictors of student satisfaction and concluded that quality of teaching, skills and knowledge acquired and the curriculum itself are the most significant factors. The student's feeling of "belonging" and his or her perceptions of the institution's responsiveness and concern also contributed significantly to overall satisfaction. From this list, it is evident that the student's output (skills and knowledge acquired) is far outweighed by the remaining attributes which reflect the institution's input. Lai, To, Lung, and Lai (2012) advocate assessing students' perceived value of higher education via functional value (the usefulness of the degree and the experiential aspect), social value, emotional value, epistemic value, and conditional value. We maintain that this value should be co-created through education involving long-term goals, not delivered to students to fulfill short-term aspirations. 


\subsection{Enhanced Moral Development}

Finally, "Enhanced Moral Development" includes those important ethical considerations advocated by the Association to Advance Collegiate Schools of Business (AACSB). Brennan, Eagle, Ellis, and Higgins (2010) argue that the conventional model for teaching ethics in college business courses is unsatisfactory. These authors view current ethics teaching as "token" and question whether teachers truly recognize their role in mapping the terrain of moral impulse in business for their students. They conclude that concern for "the Other" has been displaced by business philosophy of reason, calculation, and an identity of "same" (Brennan et al., 2010).

In response to the many scandals that have shaken corporate America, business leaders have called for effective models promoting ethical development of business education. One such model, the Deliberate Psychological Education (DPE), was examined by Schmidt, McAdams, and Foster (2009) and found to hold promise for developing ethical business professionals through preparatory classroom intervention. Steven Sample (2010), former president of the University of Southern California, calls for university professors to help students learn to wrestle with thorny questions in an effort to develop intellectual and moral autonomy and take responsibilities for their actions. While higher education is currently occupied with accessibility, globalization, funding, and innovation, Sample (2010) believes that moral education, specifically, the pursuit of wisdom, must be a top priority if students are to navigate the future.

The proposed framework offers an arguably more comprehensive and defensible set of criterion (psychologically and epistemologically) upon which to assess faculty performance. We believe that how faculty performance is evaluated will have a stout effect on pedagogical outcomes over time. That said, specifically how to operationalize the measurement of these dimensions await future research.

\subsection{Encouraging the View of Education as a Public Good}

The perspective presented herein is also consistent with the traditional view of education as a public good. We fear that long-term societal benefits are similarly at risk under a marketized education system and thus, a return to a focus on society via a marketing perspective appears in order. As human societies we are simply not very good at critical thinking (Rudinow, Barry, \& Letteri, 2008). Waychal et al. (2011) link critical thinking with innovation at the individual level of analysis. The benefits of innovation are well recognized in business practices. Cederblom and Paulsen (2006) argue that the practice of critical thinking can promote substantial social values. This view appears in line with Meisel and Fearon's (2006) association between cognitive skills such as critical thinking and ethical decision making. In addition, many of the benefits identified by Damer (2013) above sum to generalize to society at large given that societies are aggregations of individuals. Thus, generally lower critical thinking skills have both individual and societal implications. These implications should arguably be sought, nourished, and protected.

The debate over higher education as a public or private good also leads us to consider students' cognitive evaluation of their positive psychological adjustments such as personal growth, personal expressiveness, positive relationships with others, self-actualization, and the meaning and purpose of life (Ryff, 1989, 1995; Berk, 2006). One aspect of this public good is providing students with enlightenment and empowerment in the long term. Enquiry-based learning or EBL (inciting students to question context, to find information that supports understanding the principles behind the problem, and to reflect on wider implications) is one approach to increase student well-being and help them flourish (Summerlee \& Murray, 2010). These authors found that students exposed to enquiry-based learning performed at significantly higher levels than members of a control group that were not exposed to EBL. While those within higher education see EBL as contributing to the eudaimonic state of our students, it is possible that students do not and will not desire this approach to learning. If so, whose voice will be heard the loudest in higher education, the faculty or the students? Higher education is after all, a "good" simultaneously produced by both. The answer depends on whether one views higher education as a public or private good. In another study, social engagement in college activities was positively related to early career earnings, while academic engagement was not (Hu \& Wolniak, 2010). Again, how we react to these findings depends on whether one views higher education as a right or a privilege and if one believes it is a public or private good. Higher education professionals are at a precipice. We must choose to view our offering as a public good with a long-term vision of eudemonia rather than a short-term vision of strictly job placement.

\subsection{A Word about Measurement Methods}

As noted previously, many universities today continue to use simplistic, theoretically barren attribute lists of faculty and courses based on student perceptions captured by Likert scales. That is, they are often not designed to measure a specific concept such as student satisfaction or educational quality. Rather, they are relatively arbitrary tests of attributes presented in the form of an index (not scales). This data is then typically summarized 
and used for evaluative purposes via mean analyses. We call for the use of stronger emerging analytical methods to analyze such data. Mackenzie, Podsakoff and Podsakoff (2011) assert that validating measures of constructs is a critical step to building cumulative knowledge. These authors identify a number of limitations in existing scale development procedures, including (1) failure to adequately define the construct domain, (2) failure to correctly specify the measurement model, and (3) underutilizations of some techniques that are useful in establishing construct validity. All of these criticisms appear to relate to student evaluations and faculty assessments. Mackenzie et al. (2011) provide a scale development procedure that builds upon the weight of the evidence in the literature to that point. Marketing educators are encouraged to seriously consider their recommendations in scale development activities.

In addition, there have been a couple of more recent developments that service researchers are encouraged to additionally consider in validating measurement models prior to analysis when using self-report data. Taylor and Ishida (2010) propose a three-phase framework to assess satisfaction-based measurement models relying on self-reports that can be extended more generally to service research to build upon MacKenzie et al.'s (2011) recommendations. They first propose exploratory factor analysis (EFA) using structural equation analysis based upon the method recommended by Asparouhov and Muthen (2009) when EFA is required. Second, assessment of measurement scale invariance is also advocated as a regular practice of scale validation in service research. Measurement invariance refers to measurement equivalence across populations (and their subgroups). Without measurement invariance, (knowingly or unknowingly) researchers invoke assumptions about measurement equivalence in conducting tests of substantive hypotheses. Finally, Taylor and Ishida (2010) recommend the use of marker variables (Williams, Hartman, \& Cavazotte, 2010) to assess potential common method variance associated with self-reports as a measurement model. Such variance can arise from respondent's consistency motifs, transient mood states, illusory correlations, item similarity, and social desirability.

\section{Conclusion}

The basis for the proposed theoretical model involves an attempt to close the gap between pressures to educate versus train the next generation of university students as we move forward during this revolutionary point in time We concur with calls to return to the view of university education as a public good, not a private commodity (Lynch, 2006; Cucchiara et al., 2011; Whitty \& Power, 2000). New models of higher education must both enlighten and empower students to achieve their potential in the long-term. The collective goal for faculty and students alike must be to educate for a lifetime, not simply train for an immediate job opportunity.

\section{References}

Arora, R., \& Singer, J. (2006). Cognitive and affective service marketing strategies for fine dining restaurant managers. Journal of Small Business Strategy, 17(1), 51-61.

Arum, R., \& Roksa, J. (2011). Academically adrift: Limited learning on college campuses. Chicago, IL: The University of Chicago Press.

Asparouhov, T., \& Muthen, B. (2009). Exploratory structural equation modeling. Structural Equation Modeling, 16, 397-438. http://dx.doi.org/10.1080/10705510903008204

Bagozzi, R. P. (1997). Goal-directed behaviors in marketing: Cognitive and emotional perspectives. Psychology \& $\quad$ Marketing, 14(6), 539-543. http://dx.doi.org/10.1002/(SICI)1520-6793(199709)14:6<539::AID-MAR1>3.0.CO;2-8

Bagozzi, R. P., Gurhan-Canli, Z., \& Priester, J. R. (2002). The social psychology of consumer behavior, Applying social psychology series. Buckingham: Open University Press.

Bar, T., Kadiyali, V., \& Zussman, A. (2009). Grade information and grade inflation: The Cornell experiment. Journal of Economic Perspectives, 23(3), 93-108. http://dx.doi.org/10.1257/jep.23.3.93

Bauer, J. J., \& McAdams, D. P. (2010). Eudaimonic growth: Narrative growth goals predict increases in ego development and subjective well-being 3 years later. Developmental Psychology, 46(4), 761-772. http://dx.doi.org/10.1037/a0019654

Behar-Horenstein, L. S., \& Niu, L. (2011). Teaching critical thinking skills in higher education: A review of the literature. Journal of College Teaching \& Learning, 8(2), 25-41.

Berk, L. E. (2006). Child Development (7th ed.). Boston, MA: Pearson.

Bloom, B. S. (1956). Taxonomy of educational objectives: The classification of educational goals. In Handbook 1: The cognitive domain. New York, NY: David McKay Co. Inc. 
Boksberger, P. E., \& Melsen, L. (2011). Perceived value: A critical examination of definitions, concepts and measures for the service industry. Journal of Services Marketing, 25(3), 229-240. http://dx.doi.org/10.1108/08876041111129209

Boretz, E. (2004). Grade inflation and the myth of student consumerism. College Teaching, 52(2), 42-46. http://dx.doi.org/10.3200/CTCH.52.2.42-46

Bowden, J. L.-H. (2011). Engaging the student as a customer: A relationship marketing approach. Marketing Education Review, 21(3), 211-228. http://dx.doi.org/10.2753/MER1052-8008210302

Brennan, R., Eagle, L., Ellis, N., \& Higgins, M. (2010). Of a complex sensitivity in marketing ethics education. Journal of Marketing Management, 26(13-14), 1165-1180. http://dx.doi.org/10.1080/0267257X.2010.522196

Brophy, J. (1999). Toward a model of the value aspects of motivation in education: Developing appreciation for particular learning domains and activities. Educational Psychologist, 34(2), 75-85. http://dx.doi.org/10.1207/s15326985ep3402_1

Cederblom, J., \& Paulsen, D. W. (2006). Critical reasoning: Understanding and criticizing arguments and Theories. Belmont, CA: Thomson /Wadsworth.

Chapelo, C. (2010). What defines "successful" university brands? International Journal of Public Sector Management, 23(2), 169-183. http://dx.doi.org/10.1108/09513551011022519

Chen, Y., \& Oshower, L. B. (2003). Student evaluations of teaching effectiveness: An assessment of student perception and motivation. Assessment \& Evaluation in Higher Education, 28(1), 71-88. http://dx.doi.org/10.1080/02602930301683

Choy, S. C., \& Cheah, P. K. (2009). Teacher perceptions of critical thinking among students and its influence on higher education. International Journal of Teaching and Learning in Higher Education, 20(2), 198-206.

Clarke, S. (2011). Cognitive bias and collective enhancement. In J. Savulescu, R. Meulen, \& G. Kahane (Eds.), Enhancing Human Capabilities (pp. 127-149). Oxford: Wiley-Blackwell.

Clayson, D. E., \& Haley, D. A. (2011). Are students telling us the truth? A critical look at the student evaluation of teaching. Marketing Education Review, 21(2), 101-112. http://dx.doi.org/10.2753/MER1052-8008210201

Clayson, D. E., \& Sheffet, M. J. (2006). Personality and the student evaluation of teaching. Journal of MarketingEducation, 28, 149-160. http://dx.doi.org/10.1177/0273475306288402

Covington, M. V. (2000). Goal theory, motivation, and school achievement: An integrative review. Annual Review of Psychology, 51, 171-200. http://dx.doi.org/10.1146/annurev.psych.51.1.171

Cucchiara, M., Gold, E., \& Simon, E. (2011). Contracts, choice, and customer service: Marketization and public engagement in education. Teachers College Record, 11(11), 2460-2502.

Culver, S. (2010). Course grades, duality of student engagement, and students' evaluation of instructor. International Journal of Teaching and Learning in Higher Education, 22(3), 331-336.

Damer, T. E. (2013). Attacking faulty reasoning: A practical guide to fallacy-free arguments. Boston, MA: Cengage Learning.

Deci, E. L., \& Ryan, R. M. (2008). Hedonia, eudaimonia, and well-being: An introduction. Journal of Happiness Studies, 9, 1-11. http://dx.doi.org/10.1007/s10902-006-9018-1

Denson, N., Loveday, T., \& Dalton, H. (2010). Student evaluation of courses: What predicts satisfaction? Higher Education Research \& Development, 29(4), 339-356. http://dx.doi.org/10.1080/07294360903394466

Dolnicar, S., \& Grun, B. (2009). Response style contamination of student evaluation data. Journal of Marketing Education, 160-172. http://dx.doi.org/10.1177/0273475309335267

Elliott, E. S., \& Dweck, C. S. (1988). Goals: An approach to motivation and achievement. Journal of Personality and Social Psychology, 54(1), 5. http://dx.doi.org/10.1037/0022-3514.54.1.5

Ewing, A. M. (2012). Estimating the impact of relative expected grade on student evaluations of teachers. Economics of Education Review, 31, 141-154. http://dx.doi.org/10.1016/j.econedurev.2011.10.002

Flores, K. L., Matkin, G. S., Burbach, M. E., Quinn, C. E., \& Harding, H. (2012). Deficient critical thinking skills among college graduates: Implications for leadership. Educational Philosophy and Theory, 44(2), 


\section{2-230. http://dx.doi.org/10.1111/j.1469-5812.2010.00672.x}

Franz, W. I. (2010). Grade inflation under the threat of students' nuisance: Theory and evidence. Economics of Education Review, 29, 411-422. http://dx.doi.org/10.1016/j.econedurev.2009.10.013

Garbarino, E., \& Johnson, M. S. (2001). Effects of consumer goals on attribute weighting, overall satisfaction, and product usage. Psychology \& Marketing, 18(9), 929-949. http://dx.doi.org/10.1002/mar.1036

Germain, M., \& Scandura, T. A. (2005). Grade inflation and student individual differences as systematic bias in faculty evaluations. Journal of Instructional Psychology, 32(1), 58-67.

Gibson, A. (2010). Measuring business student satisfaction: A review and summary of the major predictors. Journal of Higher Education Policy and Management, 32(3), 251-259. http://dx.doi.org/10.1080/13600801003743349

Goodwin, B. (2011). Grade inflation: Killing with kindness? Education Leadership, 69(3), 80-81.

Gruber, T., Fub, S., Voss, R., \& Glaser-Zikuda, M. (2010). Examining student satisfaction with higher education services. International Journal of Public Sector Management, 23(2), 105-123. http://dx.doi.org/10.1108/09513551011022474

Hemsley-Brown, J., \& Lowrie, A. (2010). Higher education marketing. International Journal of Public Sector Management, 23(2), 1-3.

Heskett, J. L., Sasser, W. E., Jr., \& Schlesinger, L. A. (1997). The service profit chain. New York, NY: The Free Press.

Higgins, C. (2003). MacIntyre's moral theory and the possibility of an aretaic ethics of teaching. Journal of Philosophy of Education, 37(2), 279-292. http://dx.doi.org/10.1111/1467-9752.00326

Holbrook, M. B. (2005). Marketing education as bad medicine for society: The gorilla dances. Journal of Public Policy \& Marketing, 24(1), 143-145. http://dx.doi.org/10.1509/jppm.24.1.143.63906

$\mathrm{Hu}, \mathrm{S}$., \&Wolniak, G. (2010). Initial evidence on the influence of college student engagement on early career earnings. Research in Higher Education, 51, 750-766. http://dx.doi.org/10.1007/s11162-010-9176-1

Hume, M., \& Mort, G. S. (2010). The consequence of appraisal emotion, service quality, perceived value and customer satisfaction on repurchase intent in the performing arts. Journal of Services Marketing, 24(2), 170-182. http://dx.doi.org/10.1108/08876041011031136

Kohlberg, L., \& Mayer, R. (1972). Development as the aim of education. Harvard Educational Review, 42(4), 449-496.

Lai, L., To, L. S., Lung, W. M., Jane, W. Y., \& Lai, T. M. (2012). The perceived value of higher education: The voice of Chinese students. Higher Education, 63, 271-287. http://dx.doi.org/10.1007/s10734-011-9439-6

Lala, V., \& Priluck, R. (2011). When students complain: An antecedent model of students' intention to complain. Journal of Marketing Education, 33(3), 236-252. http://dx.doi.org/10.1177/0273475311420229

Langbein, L. (2008). Management by results: Student evaluation of faculty teaching and the mis-measurement of performance. Economics of Education Review, 27, 417-428. http://dx.doi.org/10.1016/j.econedurev.2006.12.003

Levacic, R. (1995). Local management of schools: Analysis and practice. Buckingham, England: Open University Press.

Lippmann, S., Bulanda, R. E., \& Wagenaar, T. C. (2009). Student entitlement: Issues and strategies for Confronting entitlement in the classroom and beyond. College Teaching, 57(4), 197-204. http://dx.doi.org/10.1080/87567550903218596

Love, D. A., \& Kotchen, M. J. (2010). Grades, course evaluations, and academic incentives. Eastern Economic Journal, 36, 151-163. http://dx.doi.org/10.1057/eej.2009.6

Lynch, K. (2006). Neo-liberalism and marketisation: The implications for higher education. European Educational Research Journal, 5(1), 1-17. http://dx.doi.org/10.2304/eerj.2006.5.1.1

MacKenzie, S. B., Podsakoff, P. M., \& Podsakoff, N. P. (2011). Construct measurement and validation Proceduresin MIS and behavioral research: Integrating new and existing techniques. MIS Quarterly, 35(2), 293-334.

Madichie, N. O. (2011). Students' evaluations of teaching (SET) in higher education: A question of reliability 
and validity. The Marketing $\quad$ Review, 11(4), 381-391. http://dx.doi.org/10.1362/146934711X13210328715984

Meisel, S. I., \& Fearon, D. S. (2006). Choose the future wisely: Supporting better ethics through critical thinking. Journal of Management Education, 30(1), 149-176. http://dx.doi.org/10.1177/1052562905280833

Molesworth, M., Nixon, E., \& Scullion, R. (2009). Having, being and higher education: The marketisation of the university and the transformation of the student into consumer. Teaching in Higher Education, 14(3), 277-287. http://dx.doi.org/10.1080/13562510902898841

Munteanu, C., Ceobanu, C., Bobalca, C., \& Anton, O. (2010). An analysis of customer satisfaction in a higher education context. International Journal of Public Sector Management, 23(2), 124-140. http://dx.doi.org/10.1108/09513551011022483

Natale, S. M., \& Doran, C. (2012). Marketization of education: An ethical dilemma. Journal of Business Ethics, 105, 187-196. http://dx.doi.org/10.1007/s10551-011-0958-y

Newman, S., \& Jahdi, K. (2009). Marketization of education: Marketing, rhetoric, and reality. Journal of Further and Higher Education, 33(1), 1-11. http://dx.doi.org/10.1080/03098770802638226

Oleinik, A. (2009). Does education corrupt? Theories of grade inflation. Educational Research Review, 4, 156-164. http://dx.doi.org/10.1016/j.edurev.2009.03.001

Oliver, R. L. (2010). Satisfaction: A behavioral perspective on the consumer (2nd ed.). London: M. E. Sharpe.

Pascarella, E. T., \& Terenzini, P. T. (2005). How college affects students, volume 2: A third decade of research. San Francisco, CA: Jossey-Bass.

Pounder, J. (2007). Is student evaluation of teaching worthwhile? An analytical framework for answering the question. Quality Assurance in Education, 15(2), 178-191. http://dx.doi.org/10.1108/09684880710748938

Rudinow, J., Barry, V. E., \& Letteri, M. R. (2008). Invitation to critical thinking. Toronto: Thomas Nelson.

Rust, R. T., Lemon, K. N., \& Narayandas, D. (2005). Customer equity management. Upper Saddle River, NJ: Pearson/Prentice Hall.

Ryff, C. D. (1989). Happiness is everything, or is it? Explorations on the meaning of psychological well-being. Journal of Personality and Social Psychology, 57, 1069-1081. http://dx.doi.org/10.1037/0022-3514.57.6.1069

Ryff, C. D. (1995). Psychological well-being in adult life. Current Directions in Psychological Science, 4, 99-104. http://dx.doi.org/10.1111/1467-8721.ep10772395

Ryff, C. D., \& Singer, B. H. (2008). Know thyself and become what you are: A eudaimonic approach to psychological well-being. Journal of Happiness Studies, 9, 13-33. http://dx.doi.org/10.1007/s10902-006-9019-0

Sample, S. B. (2010). The pursuit of wisdom: A modest, but essential, prescription for the future. Innovative Higher Education, 35, 79-89. http://dx.doi.org/10.1007/s10755-009-9133-0

Savulescu, J., Sandberg, A., \& Kahane, G. (2011). Well-being and enhancement. In J. Savulescu, R. Meulen, \& G. Kahane (Eds.), Enhancing Human Capabilities (pp. 3-18). Oxford: Wiley-Blackwell.

Schmidt, C. D., McAdams, C. R., \& Foster, V. (2009). Promoting the moral reasoning of undergraduate business students through a deliberate psychological education-based classroom intervention. Journal of Moral Education, 38(3), 315-334. http://dx.doi.org/10.1080/03057240903101556

Sheth, J. N., \& Parvatiyar, A. (2000). Handbook of relationship marketing. Thousand Oaks, CA: Sage Publications, Inc.

Sheth, J. N., Newman, B. I., \& Gross, B. L. (1991). Why we buy what we buy: A theory of consumption values. Journal of Business Research, 22(2), 159-170. http://dx.doi.org/10.1016/0148-2963(91)90050-8

Shevlin, M., Bantard, P., Davies, M., \& Griffiths, M. (2000). The validity of student evaluation of teaching in higher education: Love me, love my lectures? Assessment \& Evaluation in Higher Education, 25(4), 397-405. http://dx.doi.org/10.1080/713611436

Shiv, B., \& Huber, J. (2000). The impact of anticipating satisfaction on consumer choice. Journal of Consumer Research, 27, 202-216. http://dx.doi.org/10.1086/314320

Smith, C. A., \& Kirby, L. D. (2009). Putting appraisal in context: Toward a relational model of appraisal and 
emotion. Cognition and Emotion, 23(7), 1352-1372. http://dx.doi.org/10.1080/02699930902860386

Summerlee, A., \& Murray, J. (2010). The impact of enquiry-based learning on academic performance and student engagement. Canadian Journal of Higher Education, 40(2), 78-94.

Taylor, S. A., \& Ishida, C. (2010). A proposed framework for assessing measurement models involving self-report consumer satisfaction judgments. Consumer Satisfaction, Dissatisfaction and Complaining Behavior Conference Proceedings 2010, June 15-18, 2010 (pp. 95-107). River Forest, Illinois.

Taylor, S. A., \& Judson, K. M. (2011). A service perspective on the marketization of undergraduate education. Service Science, 3(2), 1-18. http://dx.doi.org/10.1287/serv.3.2.110

Taylor, S. A., Goodwin, S., Melton, H., \& Hunter, G. (2011a). An analysis of the student course engagement questionnaire (SCEQ) in large-section marketing principles courses. Journal on Excellence in College Teaching, 22(1), 1-29.

Taylor, S. A., Hunter, G., Melton, H., \& Goodwin, S. (2011b). Student engagement and marketing Classes. Journal of Marketing Education, 33(1), 73-92.

Vargo, S. L., \& Lusch, R. F. (2004). Evolving to a new dominant logic for marketing. Journal of Marketing, 68 , 1-17. http://dx.doi.org/10.1509/jmkg.68.1.1.24036

Waychal, P., Moharty, R. P., \& Verma, A. (2011). Leading indicators of innovation as a competence for individuals: An empirical study. Journal of Advances in Management, 8(2), 301-322.

Weiner, J. M. (2011). Is there a difference between critical thinking and information literacy? A systematic Review 2000-2009. Journal of Information Literacy, 5(2), 81-92.

White, C., \& Yu, Y. T. (2005). Satisfaction emotions and consumer behavioral intentions. Journal of Services Marketing, 19(6), 411-420. http://dx.doi.org/10.1108/08876040510620184

Whitty, G., \& Power, S. (2000). Marketization and privatization in mass education systems. International Journal of Education Development, 20, 93-107. http://dx.doi.org/10.1016/S0738-0593(99)00061-9

Wilkie, W. L., \& Moore, E. S. (2003). Scholarly research in marketing: Exploring the "4 eras" of thought development. Journal of Public Policy \& Marketing, 22, 116-146. http://dx.doi.org/10.1509/jppm.22.2.116.17639

Williams, G. L. (1995). The "marketization" of higher education: Reforms and potential reforms in higher Education finance. In D. D. Dill, \& B. Sporn (Eds.), Emerging patterns of social demand and university reform: Through a glass darkly (pp. 170-193). Oxford: Pergamon Press. http://dx.doi.org/10.1111/j.1468-2273.1995.tb01661.x

Williams, L. J., Hartman, N., \& Cavazotte, F. (2010). Method variance and marker variables: A review and comprehensive CFA marker technique. Organizational Research Methods, 13(3), 477-514. http://dx.doi.org/10.1177/1094428110366036

Yang, Z., \& Peterson, R. T. (2004). Customer perceived value, satisfaction, and loyalty: The role of switching costs. Psychology \& Marketing, 21(10), 799-822. http://dx.doi.org/10.1002/mar.20030

Zadeh, N. J., Gharakhani, D., \& Afrougheh, S. (2011). The study of confidence in university students' evaluation of faculty members. European Journal of Scientific Research, 66(2), 274-283.

Zhang, Y., \& Huang, S. (2010). How endowed versus earned progress affects customer goal commitment and motivation. Journal of Consumer Research, 37, 641-654. http://dx.doi.org/10.1086/655417

Zineldin, M., Akdag, H. C., \& Vasicheva, V. (2011). Assessing quality in higher education: New criteria for evaluating students' satisfaction. Quality in Higher Education, 17(2), 231-243. http://dx.doi.org/10.1080/13538322.2011.582796

\section{Notes}

Note 1. The Chronicle of Higher Education reported that total state support for higher education in the United States declined 7.6\% in FY 2011-2012 alone. See http://chronicle.com/article/State-Support-For-Higher/130414/

Note 2. The authors also imply the need for a better balance between consumer and citizen rights in the provision of education. 
Note 3. Whitty and Power (2000) cite Levacic (1995) as similarly suggesting that the distinguishing characteristics of a quasi-market for a public service are the separation of the purchaser from the provider and an element of user choice between providers. Whitty and Power (2000) distinguish the "privatization" of education from the "marketization" of education, stating that the latter appears a better metaphor for the recent evolution of education.

Note 4. Readers are encouraged to review the source articles for these differing perspectives.

Note 5. A consumer orientation under marketized conditions implies that (satisfaction of) individual goals drive value/loyalty perceptions. Zhang and Huang (2010) link goals, motivation, and loyalty.

Note 6. A complex laddering technique may be required to get people to identify their abstract goals (Garbarino \& Johnson, 2001).

Note 7. Franz (2010) identify the potential threat that students' nuisance can also induce professors to inflate grades. Importantly, we are not asserting that a reliance on student evaluations is the sole reason for grade inflation. Rather, it is a strong association.

Note 8. In fairness, Boretz (2004) asserts that foundations related to consumerism do not explain grade inflation. Rather, she contends that the rise of faculty development programs and increased student support services provide a better explanation of (what she agrees is) higher grade averages over time. Bar, Kadiyali, and Zussman (2009) argues that part of grade inflation can be explained by student selection of "easier" courses and instructors. However, the preponderance of evidence suggests that marketization, subsequent student consumerism, a growing focus on student evaluations are defensible antecedents to grade inflation.

\section{Copyrights}

Copyright for this article is retained by the author(s), with first publication rights granted to the journal.

This is an open-access article distributed under the terms and conditions of the Creative Commons Attribution license (http://creativecommons.org/licenses/by/3.0/). 